by Dr. Charles A. Perera, who contributes a kindly appreciation of Dr. May to the Arch. of Ophthal. (January, 1944) from which journal the above facts are abstracted with grateful acknowledgements.

\title{
R. J. COULTER
}

\section{Mr. Harrison Butler writes :-}

The death of R. J. Coulter on April 9, after a long and painful illness is a grief to his many friends not only in the ophthalmic world but to a large number of general practitioners in Newport and Monmouthshire, where he practised for over forty years.

Coulter was born at Dundalk and was educated at the Dundalk Grammar School. He lost his father and mother before he was three years old and was brought up by his aunts and an uncle. From Dundalk he continued his education at Trinity College, Dublin, and took his B.A., M.B., B.Ch. and B.A.O. of the University of Dublin in 1892. In 1899 he became a Fellow of the Irish Royal College of Surgeons.

He was House Surgeon to Sir Henry Rosborough Swanzy, in Dublin, and then to Mr. Richardson Cross at Bristol. These posts under such distinguished surgeons gave him the opportunity of acquiring a sound grounding in the principles and practice of ophthalmology, an opportunity of which he took full advantage. It was characteristic of Coulter that he never lost any chance of increasing his knowledge and experience. He became a Member of the Ophthalmological Society of the United Kingdom in 1898, forty six years ago. He was an original member of the Oxford Congress and for many years held the office of Treasurer. He was also Treasurer and President of the South Western Ophthalmological Society. Not only was he a member of these societies but he was a constant attendant and took part in many of their discussions. His remarks were always distinguished by sound common sense and an obvious practical knowledge of clinical ophthalmology. He was such a constant figure at the Oxford Congress that many of us will feel that the Congress is not the same without him.

Coulter was elected Ophthalmic Surgeon to the Royal Gwent Hospital in 1901, and held the post with great distinction till 1932 when he retired on the age limit. His early education made him eminently fitted to make the most of this appointment, and he gained a very high reputation in the neighbourhood, and indeed far beyond his immediate district.

I have a letter from his successor at the Royal Gwent, Mr. F. W. Robertson, which gives a picture of his activities at the Hospital. He says : "His death leaves another gap in ophthalmology in this part of the country. I was his House Surgeon in 1919 and 1920, and it was he who encouraged me to specialise in ophthalmology. 
He taught me a great deal not only what to do but what not to do. He was very helpful and only gave his valuable opinion after a careful weighing up of the data and evidence. I have always proved his opinion to be absolutely sound and it was of very great help to me in my earlier days in ophthalmology. . His operative work was very good and he left a very fine collection of intra-ocular foreign bodies which he had removed during his working years. His end was unfortunately a hard one. For months he suffered a great deal of pain, but he proved an excellent patient. So passeth a man who was at all times a gentleman to the highest ethical code, sound, patient, kind, charitable, always ready to help with a kind word of advice."

I first met Coulter at the Oxford Congress in 1910, and commenced a friendship which lasted till his death. He was one of a circle of ophthalmic friends, many now no longer with us ; Cridland, Russ Wood, Sydney Stephenson, and many others. Coulter was very diffident and unconscious of his own powers, but those who knew him appreciated his real worth. He did not write very much, but he contributed a sound article on "Injuries to the Eye," in Greer's Industrial Diseases and Accidents.

Coulter gave The Montgomery Lecture in 1928. He examined in ophthalmology for the National University of Ireland. He gained the Oxford Diploma in Ophthalmology in 1911. Coulter took a leading part in the activities of the British Medical Association in South Wales, being. Treasurer and Ex-President of the South Wales and Monmouth Branch. He was a Member of the Société française d'ophtalmologie. In 1923 Coulter and I attended the course on the slit-lamp given at $Z$ ürich by Professor Vogt, and he had previously studied at Vienna. Coulter leaves a wife, a daughter and a son.

The world is poorer by the loss of Coulter, and his friends are conscious that they have lost a real friend.

\section{SANFORD R. GIFFORD}

WE regret to announce the death from pneumonia of Sanford $R$. Gifford, at the early age of 52 years. He served as a first-lieutenant in the last war in France, and then returned to Omaha where he joined his father in practice. In 1929 he became Professor and Chairman of the Department of Ophthalmology at Northwestern University Medical School, which post he held with distinction until the time of his death.

Gifford was a prolific writer and was associate editor of the Archives of Ophthalmology. His best known work in this country is probably his " Handbook of Ocular Therapeutics," an authoratative treatise on the treatment of eye disease, and full of useful information. One of his principal interests was the role of fungi 